\title{
Teknologi Pengolahan Pakan Amoniase Pada Sapi di Desa Nggorang, Kecamatan Komodo Manggarai Barat, NTT
}

\author{
Nemay Ndaong ${ }^{*}$, Annytha Detha ${ }^{2}$, Frans Umbu Datta ${ }^{3}$, Nancy Foeh $^{4}$, Grace Maranatha ${ }^{5}$
}

1,2,3,4,5 Fakultas Peternakan, Universitas Nusa Cendana Kupang

A R T I C L E I N F O

Article history:

Received 20 August 2019

Received in revised form

10 September 2019

Accepted 30 October 2019

Available online 30

November 2019

\section{Kata Kunci:}

Agrowisata, Amoniase,

Nggorang, Komodo

Keywords:

Agro-tourism, Amoniase,

Nggorang, Komodo

\begin{abstract}
A B S T R A K
Desa Nggorang, Kecamatan Komodo, Maggarai Barat merupakan daerah yang cukup ideal untuk pengembangan ternak dan pemanfaatan limbah pertanian karena didukung oleh beberapa faktor antara lain daya dukung wilayah tempat sumber air yang ada dapat memenuhi air masyarakat kebutuhan sepanjang tahun dan ketersediaan limbah pertanian jerami padi. Tujuan dari pelaksanaan pelatihan pemrosesan pakan amoniase adalah untuk memaksimalkan produktivitas peternakan sapi dengan memanfaatkan ketersediaan sumber daya alam sambil memberdayakan limbah pertanian jerami padi sebagai sumber pakan utama dengan memanfaatkan teknologi pemrosesan pakan. Oleh karena itu, pelatihan teknologi pengolahan pakan jerami telah menjadi limbah pertanian terbesar di Desa Nggorang. Berdasarkan hasil kegiatan yang ada, ada peningkatan pemahaman petani yang dicapai. Dengan demikian desa Nggorang diharapkan mampu meningkatkan kemandirian masyarakat desa melalui kelompok tani mitra yang mampu mengoptimalkan produktivitas ternak melalui kemandirian dan kecukupan pakan ternak di Desa Nggorang, Kecamatan Komodo, Manggarai Barat, NTT
\end{abstract}

\section{A B S T R A C T}

Nggorang Village, Komodo District, West Maggarai is an area that is quite ideal for the development of cattle and agricultural waste utilization because it is supported by several factors, among others, the carrying capacity of the region where existing water sources can meet the community's water needs throughout the year and the availability of rice straw agricultural waste. The purpose of implementing amoniase feed processing training is to maximize the productivity of cattle farms by utilizing the availability of natural resources while empowering rice straw agricultural waste as the main source of feed by utilizing feed processing technology. therefore, training in rice straw feed processing technology has become the largest agricultural waste in Nggorang Village. Based on the results of existing activities, there is an increase in farmers' understanding that is achieved. Thus the Nggorang village is expected to be able to increase the independence of the village community through partner farmer groups that are able to optimize livestock productivity through the independence and adequacy of animal feed in Nggorang Village, Komodo District, West Manggarai, NTT

\footnotetext{
* Corresponding author.

E-mail addresses: nemayndaong@123gmail.com (Nemay Ndaong)
} 


\section{Pendahuluan}

Komodo merupakan satwa endemik Indonesia dan hanya dapat ditemukan di Pulau Komodo, Pulau Rinca, Pulau Padar, Gili Motang, dan Flores (Monk et al. 2000). Penetapan kelima pulau utama tersebut menjadi Taman Nasional Komodo (TNK) merupakan salah satu upaya untuk melindungi satwa komodo beserta habitatnya. Secara ekologis, komodo merupakan top predator sehingga gangguan dapat terjadi akibat putusnya rantai makanan, yaitu hilangnya vegetasi baik sebagai cover maupun sebagai sumber pakan bagi satwa herbivor, khususnya satwa ungulata yang merupakan mangsa bagi komodo. Banyaknya rusa yang dimangsa oleh anjing liar mengakibatkan ancaman terhadap menurunnya populasi komodo. Populasi komodo di Pulau Padar saat ini dianggap punah, hal ini tampaknya akibat berkurangnya populasi rusa yang merupakan salah satu satwa mangsa bagi komodo (Monk et al. 2000, Mustari et al., 2007). Terjadinya kepunahan populasi komodo di Pulau Padar yang merupakan salah satu habitat asli bagi komodo yang diakibatkan berkurangnya mangsa, menjadikan penelitian mengenai potensi mangsa komodo perlu dilakukan agar tidak terjadi lagi kepunahan, baik terhadap komodo maupun satwa mangsanya. Penelitian ini bertujuan untuk mengetahui jenis mamalia besar yang menjadi mangsa komodo di Pulau Rinca, Taman Nasional Komodo (Mustari, 2011).

Kehadiran ekosistem penyusun bentang alam Pulau Besar dan Pulau Kecil mendukung keberlanjutan populasi komodo (Varanus komodoensis). Pada tahun 1992 dan 1996, sebagian Pulau Besar dan Pulau Kecil ditetapkan sebagai taman nasional, meliputi Cagar Alam (CA) Wolo Tado, CA Riung dan Taman Wisata Alam Laut (TWAL) 17 Pulau. Pulau Besar atau Flores dan Pulau Kecil atau Ontoloe merupakan pulau di bagian Utara daerah Riung, Nusa Tenggara Timur (NTT). Bentang alam karst mendominasi Pulau Besar dan Pulau Kecil. Tipe ekosistem yang ditemukan merespon bentang alam karst yaitu daerah dengan ketersediaan air tanah yang sedikit (IUCN 2008) dan lapisan tanah yang tipis (Achmad 2011). (Blegur, 2017).

Komodo merupakan salah satu reptil langka, dilindungi dan hanya dapat ditemukan di Taman Nasional Komodo serta bagian utara Pulau Flores. Oleh karena itu, penelitian ini bertujuan menilai perkembangan parameter populasi maupun sebaran spasialnya perlu dilakukan. Pengambilan data populasi komodo dan penyebaran spasial berlangsung pada 20 transek dengan 4 kali pengulangan dimana 5 transek di hutan musim gugur dan 15 transek di savana dengan luas total pengambilan contoh 200 ha (Santosa, 2012).

Naga komodo merupakan kadal terbesar di dunia (Barnard, 2011). Wisatawan mulai mengunjungi pulau-pulau sejak ditemukannya naga komodo yang merupakan atraksi utama dari wilayah ini (Hitchcock, 1993 dalam Walpole dan Goodwin, 2001). Naga komodo khususnya menarik jumlah kunjungan yang besar terutama wisatawan dari negara-negara barat ke sebuah wilayah terpencil di Indonesia (Walpole dan Leader-Williams, 2002). Naga komodo merupakan aset terpenting dari TNK dan menjadi kebanggaan masyarakat Indonesia (Iriyono, dkk., 2013) (Ziku, 2015).

Desa Nggorang Kecamatan Komodo adalah salah satu desa di Kabupaten Manggarai Barat Nusa Tenggara Timur. Desa ini memiliki potensi di sektor pariwisata karena scara lokasi berdekatan dengan labuan bajo sebagai pusat pariwisata di wilayah NTT. Selain dalam sektor pariwisata, Desa Nggorang juga memiliki potensi peternakan dan pertanian yang sangat menjanjikan. Berdasarkan data dinas peternakan kabupaten Manggarai Barat, ternak besar antara lain sapi, kuda dan kerbau memiliki jumlah yang besar yang dapat dilihat pada Tabel 1 tentang data populasi ternak. Berdasarkan data, ternak sapi tercatat berjumlah 17.248 pada tahun 2015 dan 18.249 pada tahun 2016. Demikian pula ternak kerbau sejumlah 19300 pada tahun 2015 dan 20.026 pada tahun 2016. Sedangkan untuk ternak babi sejumlah 43.549 pada tahun 2015 dan 41.985 pada tahun 2016 (Dinas Peternakan Kabupaten Manggarai Barat 2017). Sektor pertanian juga merupakan unggulan di kabupaten ini karena dapat meningkatkan perekonomian Kabupaten Manggarai Barat. Berdasarkan Data Produksi Tanaman Pangan Kabupaten Manggarai Barat, tercatat bahwa sejumlah tanaman pertanian yang merupakan unggulan yaitu Produksi Padi, Padi Sawah, Padi Ladang, Jagung, Kedelai, Kacang Tanah, Ubi Kayu dan Ubi Jalar (Dinas Pertanian Manggarai Barat, 2018).

Secara garis besar, Desa Nggorang Kecamatan Komodo, Kabupaten Maggarai Barat merupakan daerah yang cukup ideal untuk pengembangan ternak sapi dan pemanfaatan limbah pertanian karena didukung oleh beberapa faktor antara lain daya dukung wilayah dimana sumber air yang ada dapat mencukupi kebutuhan air masyarakat sepanjang tahun dan agroekosistem masih didominasi oleh padang penggembalaan yang dapat mencukupi kebutuhan. Selain itu Desa Nggorang juga memiliki potensi sumber daya ternak yang tinggi terutama sapi dan kerbau, dan potensi sumber daya yang tidak terpisahkan dari sistem usaha tani yang tidak terpisahkan dengan kehidupan petani, serta daya dukung ketersediaan pakan, ketersediaan pakan hijauan dari padang penggembalaan dan rumput sekitar areal pertanian serta limbah pertanian (jerami) yang cukup tinggi (Sutanto 2002). 
Berdasarkan hasil observasi, terdapat beberapa faktor yang menghambat produktivitas peternakan di desa Nggorang diantaranya yaitu keterbatasan pakan terus menjadi permasalahan yang dihadapi oleh hampir semua peternak secara khusus pada musim kering yang waktunya lebih lama dari musim penghujan, dan minimnya keterampilan mengolah pakan menggunakan limbah hasil pertanian. Oleh kerena itu dengan memanfaatkan teknologi yang ada, maka dilakukan pelatihan pembuatan Amoniase untuk meningkatkan kapasitas peternak Desa Nggorang dalam menghasilkan pakan dari limbah pertanian yang bernilai gizi baik bagi ternak.

\section{Metode}

Survei awal terhadap lokasi tempat pelatihan dilakukan pada Bulan Oktober 2018 di Desa Nggorang, Kecamatan Komodo, Kabupaten Manggarai Barat. Tempat survei awal di lakukan di tiga kelompok peternak yang ada di Desa Nggorang dan Kantor Desa Nggorang. Kegiatan pelatihan pembuatan Bokashi dilakukan pada tanggal 22 hingga 25 Agustus 2019 yang berlokasi di Gedung Pertemuan kantor Desa Nggorang.

Metode pendekatan yang ditawarkan untuk mendukung ketercapaian tujuan di Desa Nggorang melalui pendidikan dan pelatihan yang disertai dengan pembuatan model percontohan dan pendampingan serta monitoring evaluasi. Pendidikan dan pelatihan dilakukan dalam dua jenis yang diarahkan untuk peningkatan pengetahuan atau pemahaman peternak dalam hal manajemen pemeliharaan ternak yang baik melalui penyediaan pakan dalam rangka meningkatkan produk peternakan dari ketiga kelompok mitra. Pelatihan ini dititikberatkan pada teknik pembuatan pakan yang berasal dari sumber daya lokal dan teknik pembuatan amoniase limbah hasil pertanian sehingga diharapkan peternak dapat menerapkan ini secara baik untuk dapat memenuhi kebutuhan pakan.

Metode pencapaian tujuan juga dilakukan simulasi pembuatan Amoniase guna meningkatkan tingkat adopsi kelompok peternak dalam pembuatan pakan Amoniase yang berasal dari sumber daya lokal dimiliki peternak atau yang mudah diperoleh peternak. Model percontohan ini dilakukan di kandang percontohan yang dibuat di lahan peternak dan menggunakan jerami padi sebagai limbah hasil pertanian yang dapat dimanfaatkan sebagai pakan ternak. Kegiatan pendampingan yang konsisten dijalankan selama kegiatan juga dilakukan untuk menjamin keberlanjutan program.

Monitoring dan evaluasi akan dilakukan guna melihat perubahan perilaku kelompok peternak terutama ketiga kelompok mitra program yang berkaitan dengan berbagai manfaat yang diperoleh. Evaluasi dilakukan setelah berlangsungnya rangkaian kegiatan pendidikan dan pelatihan, serta kegiatan model percontohan sistem pemeliharaan yang baik. Pada aspek pendidikan dan pelatihan dilakukan sebelum dan sesudah kegiatan penyuluhan. Tujuan evaluasi pendidikan dan pelatihan adalah untuk mengetahui tingkat pemahaman dan keterampilan awal dan pada akhir kegiatan. Dari segi tingkat penerapan pembuatan pakan silase yang memanfaatkan pakan lokal, akan dievaluasi sesuai metode yang telah diajarkan dan sesuai urutan kerja.

\section{Hasil dan pembahasan}

Berdasarkan pendekatan metode pelaksanaan yang dirancangkan, kegiatan pelatihan diawali dengan kegiatan surveillance yang berkaitan dengan ketersediaan aktif peternak desa Nggorang pada bulan Oktober 2018. Pertemuan awal dilakukan untuk memastikan keikutsertaan mitra Desa yang diwakili oleh Kepala Desa dan Mitra Kelompok Tani yang sudah menandatangani kesepakatan kerjasama. Pada saat survei awal, juga dilakukan pendataan ketersediaan bahan pelatihan pembuatan amoniase. Kegiatan inti pelatihan dilakukan dalam 4 tahap yaitu pelatihan, simulasi pembuatan amoniase, pendampingan, dan evaluasi.

Secara umum pelatihan pembuatan Amoniase diselenggarakan pada tanggal 22 hinga 25 Agustus 2019. Tempat pelatihan dilakukan di Gedung Pertemuan, Kantor Desa Nggorang. Pelatihan ini diikuti oleh 30 peserta yang terdiri dari anggota kelompok ternak "Tunas Karya". Materi pelatihan dan pendidikan ini diarahkan untuk peningkatan pengetahuan/pemahaman peternak dalam hal manajemen pemeliharaan ternak yang baik melalui penyediaan pakan dan pengenalan teknologi pembuatan pakan yang berasal dari sumber daya lokal (Amoniase) dengan memanfaatkan jerami padi sebagai limbah hasil pertanian yang sangat melimpah di Desa Nggorang.

Selain pelatihan, kegiatan pengenalan teknologi pengolahan pakan dari jerami padi berupa simulasi atau demplot juga dilakukan. Simulasi pembuatan Amoniase dilakukan di halaman depan kantor desa Nggorang. Peserta secara aktif mengikuti pelatihan ini dan secara aktif mengikuti proses pembuatan amoniase. Dalam simulasi pembuatan Amoniase dari rumput setengah kering atau kering dilakukan sebagai sebagai berikut yaitu sejumlah 1000 gram bahan kering Jerami padi, Urea 5\%, Air 50\% dan 
Molases sejumlah 30\%. Seluruh jerami dimasukkan dalam kantong plastik atau drum, lalu urea dilarutkan dengan mencampur 870 gram ke dalam ember yang berisi 5 liter air, diaduk-aduk sampai semua urea larut. Urea dicampur dengan jerami, diaduk-aduk sampai merata seluruhnya. Kemudian jerami di dalam plastik atau drum dipadatkan (sesuai kekuatan plastik atau drum) lalu drum atau plastik ditutup atau diiikat dan selanjutnya disimpan selama 4 minggu, amoniasi jerami padi dapat dibuka. Sebelum diberikan ternak jerami padi amoniasi tersebut harus diangin-anginkan selama 1- 2 hari (Bata, 2008).
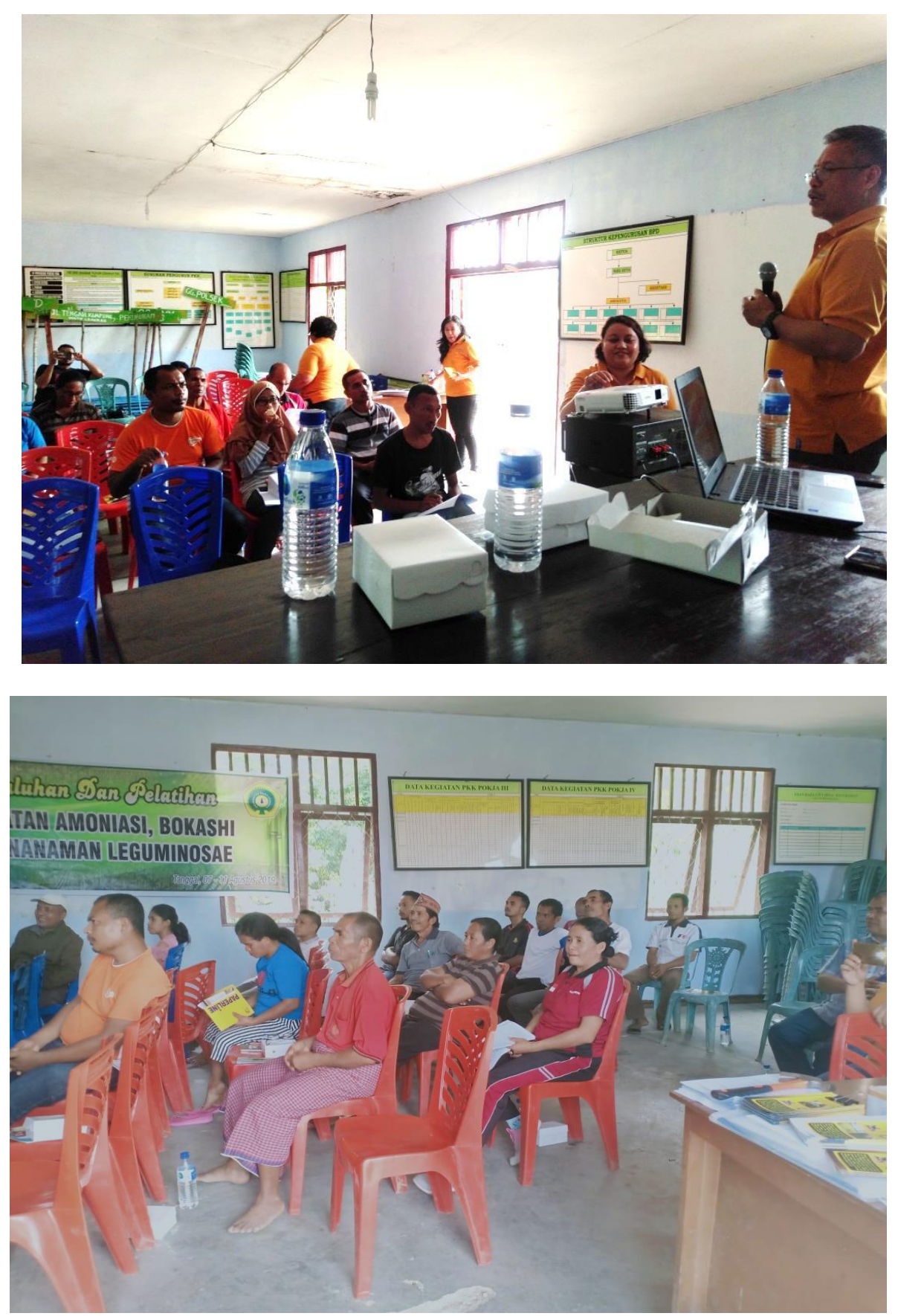

Gambar 1. Pelatihan pebuatan Amonise 

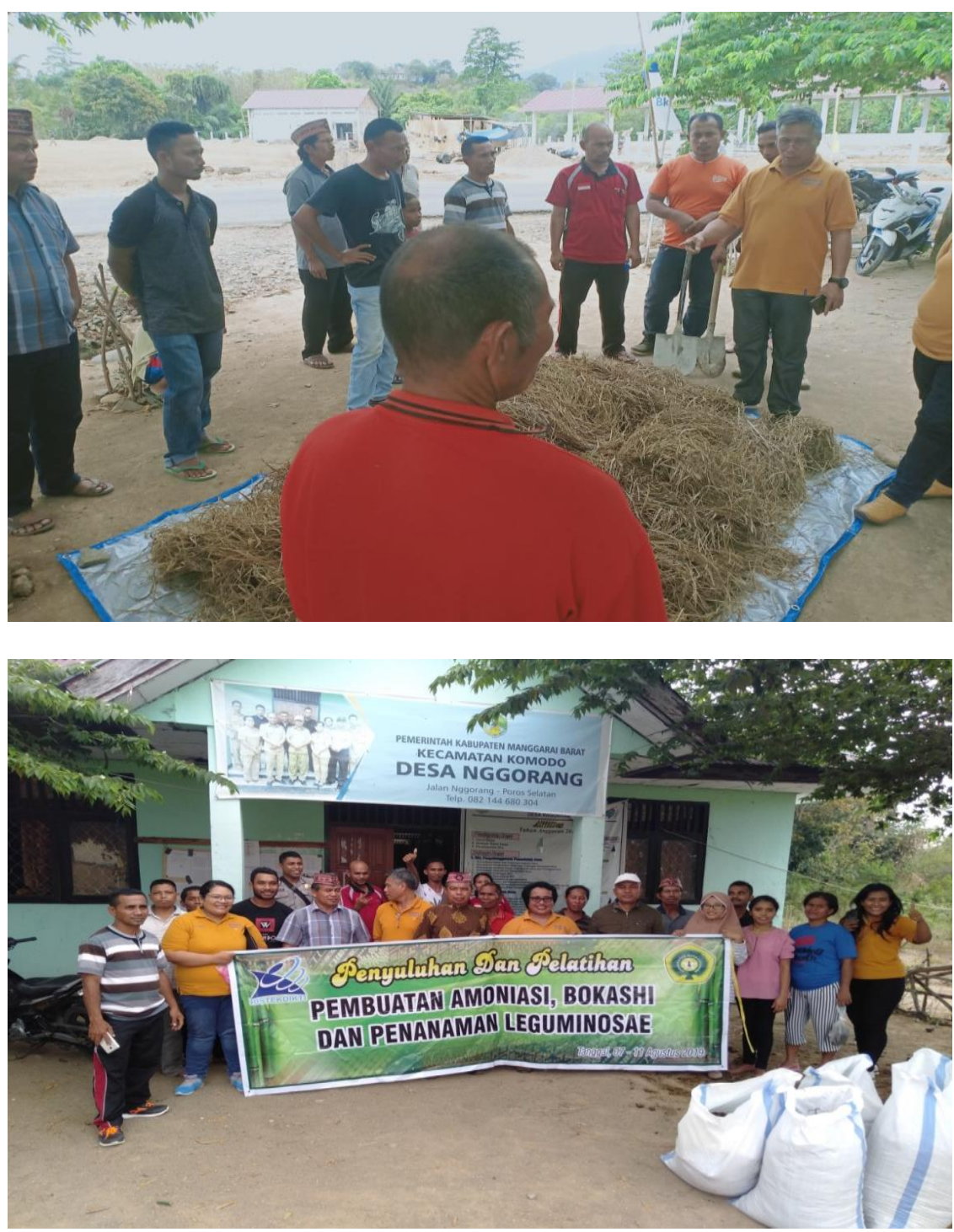

Gambar 2. Simulasi pembuatan Amoniase

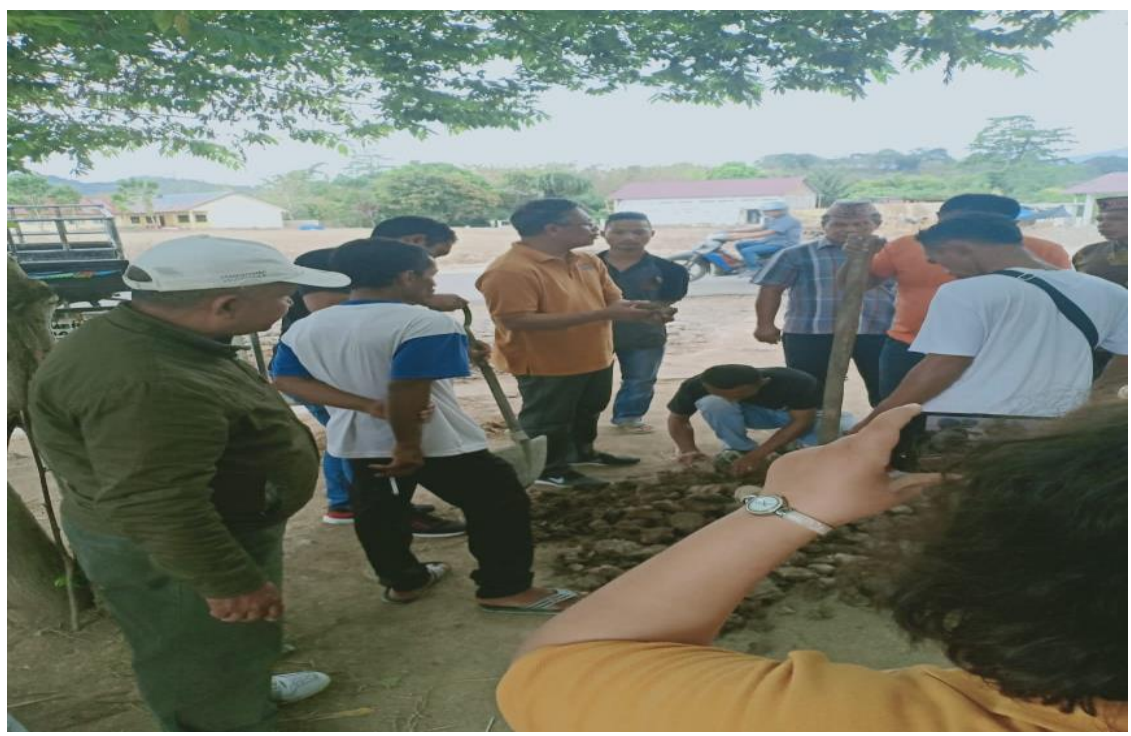

Gambar 3. Diskusi dan tanya jawab terkait kendala pengolahan limbah jerami padi 
Kegiatan pendampingan yang konsisten dijalankan selama kegiatan pelatihan dalam bentuk tanya jawab masalah yang dihadapi peternak dan kendala yang menghambat pengolahan jerami padi menjadi amonise. Kegiatan pendampingan ini juga dapat menjadi salah satu jamin keberlanjutan program.

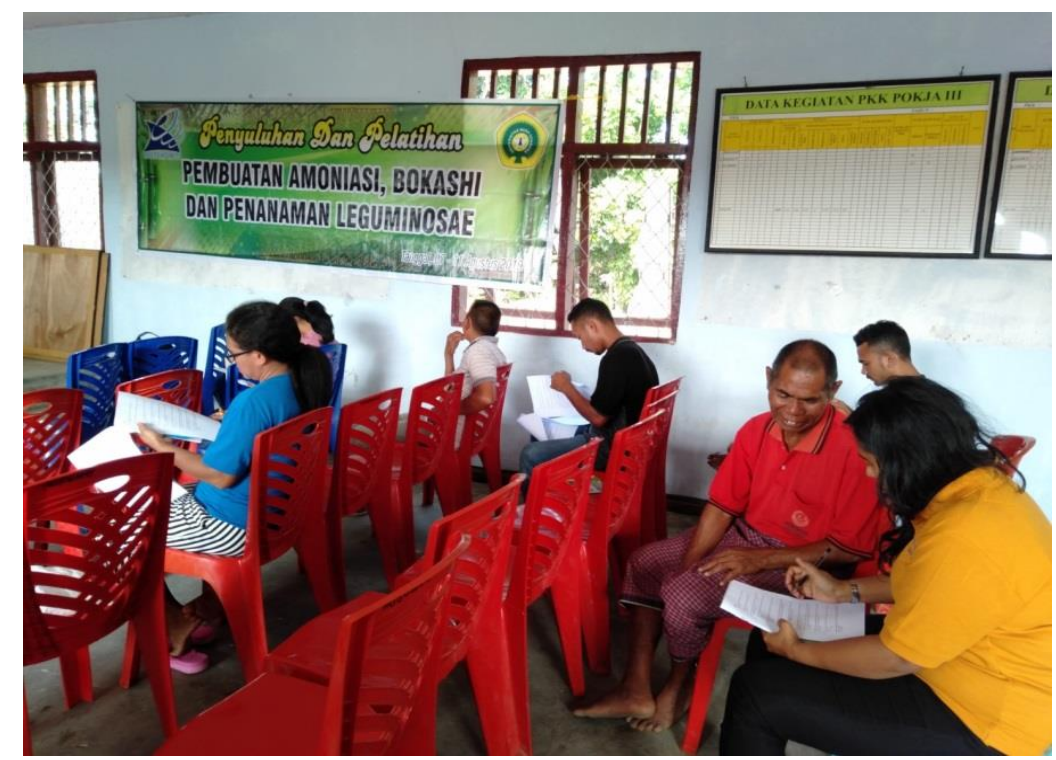

Gambar 4. Evaluasi keberhasilan pelatihan

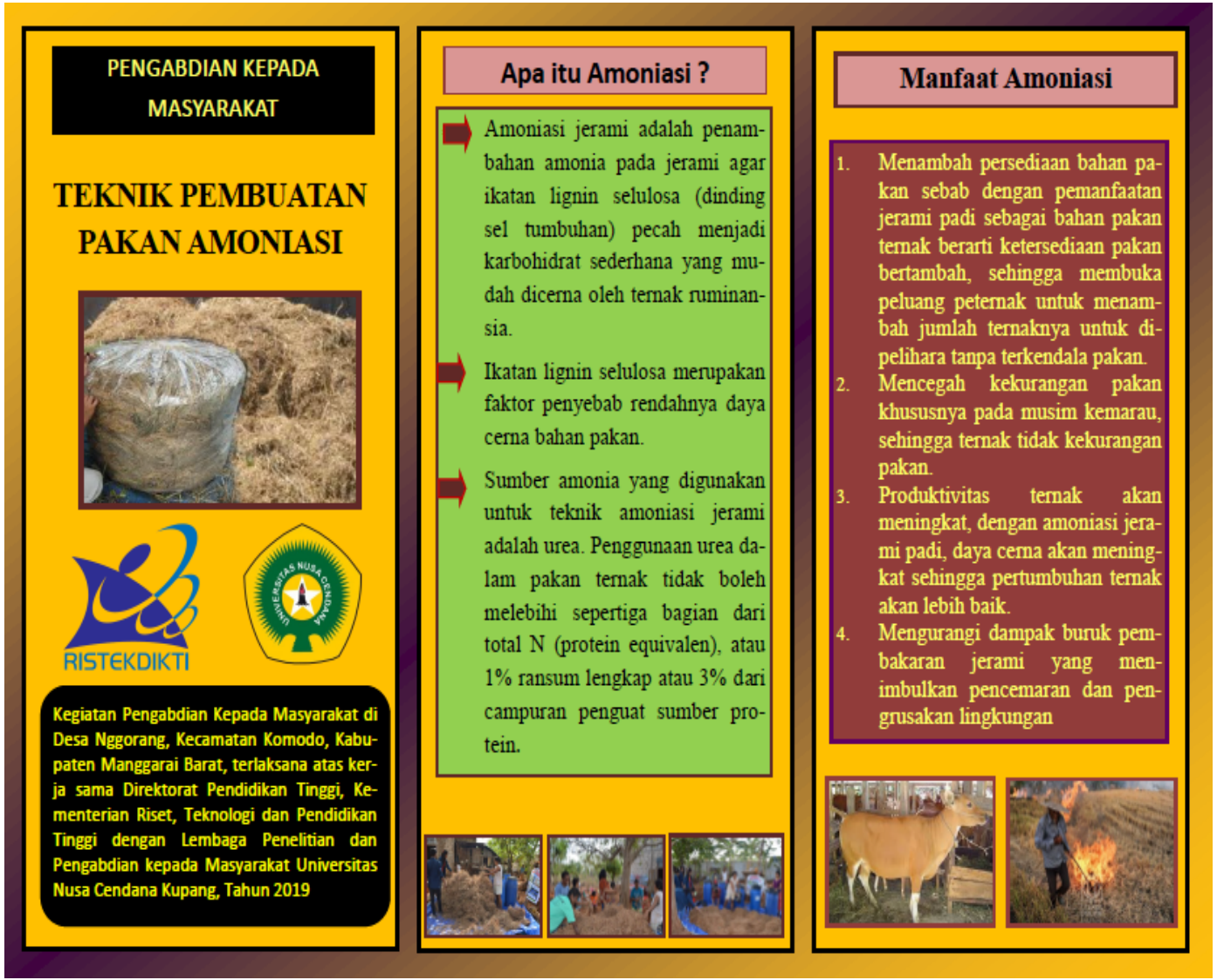

Gambar 4. Leaflet pembuatan Amonilase yang dibagikan pada peternak 


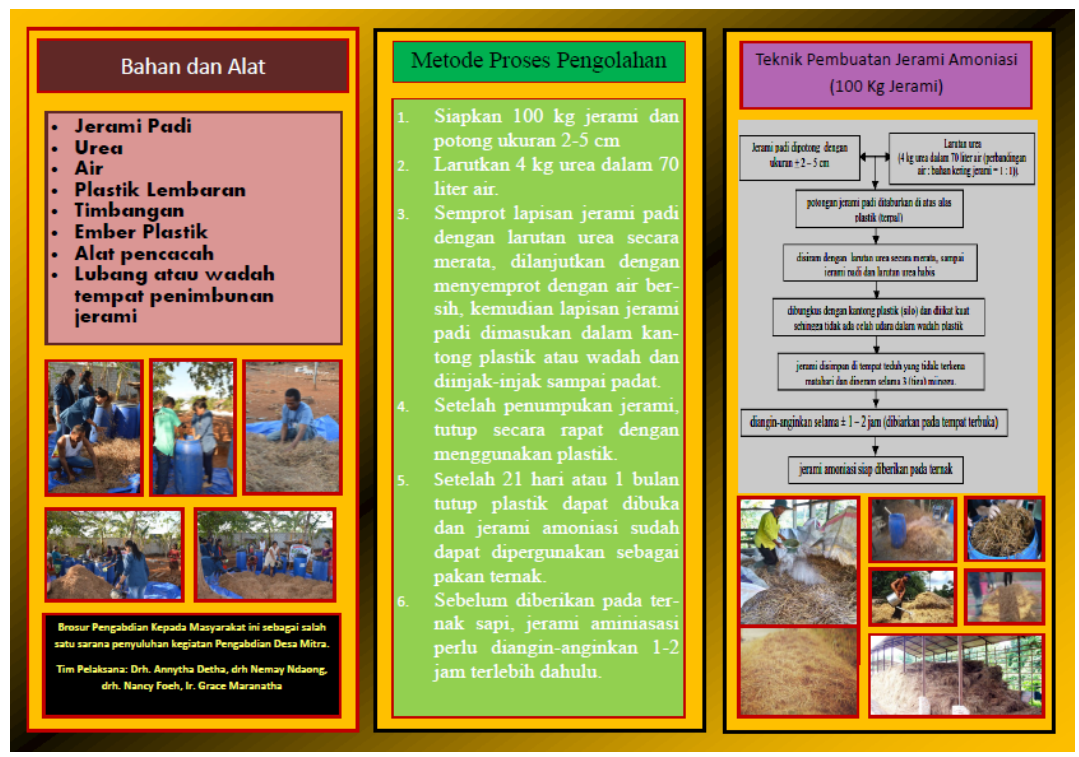

Gambar 4. Leaflet pembuatan Amonilase yang dibagikan pada peternak

Untuk mengukur keberhasilan pelatihan, pada akhir pelatihan dilakukan evaluasi sejauhmana peserta dapat menyerap materi yang diberikan. Alat ukur yang digunakan untuk evaluasi dengan menyebarkan kuesioner yang berisi pertanyaan seputar kegiatan pelatihan dan simulasi yang telah dilakukan. Berdasarkan hasil kuesioner yang disebarkan, semua peserta menjawab dapat memahami materi dengan baik dan mampu mengimplementasikannya karena bahan-bahan yang dibutuhkan, sangat mudah diperoleh.

\section{Simpulan dan saran}

Kegiatan pelatihan pembuatan Amoniase dapat meningkatkan kapasitas peternak dalam mengolah pakan ternak dari limbah pertanian yang tersedia di lingkungan, sekaligus menunjang kemandirian peternak agar mampu mengoptimalkan produktivitas peternakan melalui peningkatan pemanfaatan limbah pertanian menjadi pakan yang bernilai gizi baik. Penulis mengucapkan terima kasih kepada Direktorat Jenderal Pendidikan Tinggi, Kementerian Riset, Teknologi, dan Pendidikan Tinggi yang telah mendanai kegiatan pengabdian di desa Desa Nggorang, Kecamatan Komodo, Kabupaten Manggarai Barat, NTT. Ucapan terima kasih juga diberikan kepada Lembaga Penelitian dan Pengabdian Universitas Nusa Cendana yang memberikan sarana dalam bentuk in kind dalam mendukung kegiatan pengabdian ini.

\section{Daftar Rujukan}

Blegur, Willem Amu. 2017. Vegetasi Habitat Komodo dalam Bentang Alam Riung dan Pulau Ontoloe di Nusa Tenggara Timur. Jurnal Majalah Geografi Indonesia Vol. 31, No.1, Maret 2017 Fakultas Geografi UGM dan Ikatan Geograf Indonesia (IGI)

Bata M. 2008. Pengaruh Molases Pada Amoniasi Jerami Padi Menggunakan Urea Terhadap Kecernaan Bahan Kering dan Bahan Organik In Vitro. Agripet Vol 8(2): 15-20.

Detha A, Ndaong N, Foeh N, Datta FU. 2019. Karakteristik Bakteri Asam Laktat Yang Diisolasi Dari Susu Kuda Sumba. Jurnal Kajian Veteriner 7(1): 85-92.

Dinas Peternakan, Kabupaten Manggarai Barat. 2018. Data Ternak Kabupaten Manggarai Barat Tahun 2015 dan 2016. Pemerintah Kabupaten Manggarai Barat.

Dinas Tanaman Pangan, Hortikultural dan Perkebunan Manggarai Barat. 2018. Produksi Komoditi Pertanian Kabupaten Manggarai Barat Tahun 2015, 2016, dan 2017. Pemerintah Kabupaten Manggarai Barat. 
Foeh N, Datta FUD, Detha A, Ndaong N. 2018. Isolation Of Lactic Acid Bacteria From Ruments Of Cattle As A Starter In The Manufacture Of Silage. Prosiding Seminar Internasional “5th ICAMBBE 2018, Swiss Belinn Hotel Malang, 3-4 September 2018".

Mustari, Abdul Haris . 2011. Potensi Mamalia Besar Sebagai Mangsa Komodo (Varanus Komodoensis Ouwens 1912) Di Pulau Rinca Taman Nasional Komodo Nusa Tenggara Timur . Jurnal Media Konservasi Vol. 16, No. 1 April 2011

Santosa, Yanto. 2012. Pendugaan Parameter Demografi dan Bentuk Sebaran Spasial Biawak Komodo di Pulau Rinca, Taman Nasional Komodo. Jurnal Ilmu Pertanian Indonesia (JIPI), Agustus 2012 Vol. 17 (2):

Sutanto R. 2002. Pertanian organik: Menuju Pertanian Alternatif dan Berkelanjutan. Jakarta: Kanisius.

Ziku, Rafael Modestus. 2015. Partisipasi Masyarakat Desa Komodo Dalam Pengembangan Ekowisata Di Pulau Komodo . Jurnal JUMPA Volume 2 Nomor 1 Juli 2015 